$\xi=-1$

\title{
The Relationship between Macroeconomic Factors and Stock Market Indices Performances in Indian Stock Market
}

\author{
D. Kinslin ${ }^{1 *}$, V.P. Velmurugan² \\ ${ }^{1}$ Assistant Professor and Chair of General Education, Emirates College of Management and Information Technology, Al Nahda-2, \\ Dubai. \\ ${ }^{2}$ Assistant Professor, Faculty of Management Studies, Noorul Islam Centre for Higher Education, Kumaracoil, Kanyakumari District, \\ Tamil Nadu, India. \\ *Corresponding author E-mail: kinslin@ecmit.ac.ae
}

\begin{abstract}
This investigation endeavors in observationally testing the connection between macroeconomic variables and the exhibitions of two noteworthy Indian security advertise lists of BSE-sensex and NSE-clever. The yearly information of a few macroeconomic elements of FIIs net venture, trade rates, oil value, financing costs, swelling rates and gold rates from 1995-96 to 2014-15 are thought about and it attempts to uncover the most impact of these elements on the 'Stock files exhibitions' of the Indian securities exchange. In compatibility of this, the connection investigation and various relapse examination was utilized to contemplate the connection between the two chose security advertise files exhibitions and the six chose macroeconomic elements from the Indian economy. The significant finding is that macroeconomic elements impact securities exchange lists exhibitions in India. It is suggested that the usage of appropriate monetary approaches will be useful to money markets files and it will result in required development in the Indian capital market.
\end{abstract}

Keywords: Stock market indices, stock market, stock prices, FIIs net investment, exchange rates, oil price, interest rates, inflation rates and gold rates.

\section{Introduction}

A stock trade is a managed commercial center where recorded securities are bought and sold with the assistance of individuals or stock dealers present in stock trade, by following an open arrangement of two-way citation and holding fast to the bye-laws of the stock trade.'

A few financial speculations and exact investigations have been utilized to consider stock costs and consequently money markets records are considered as the best indications of varieties in Indian monetary activities. This learned curiosity picked up command because of the expanding conviction that genuine monetary occasions regularly affect on stock qualities. Chen et al. (1986) discussed and offered that activities in macroeconomic components influence future rewards and also rebate extents, in this manner troubling stock costs. Smith (1990), in his investigation of the American stock cost conduct expresses that the watched stock costs as a rule decrease without further ado before a subsidence induces and increment in a matter of seconds before the retreat closes. Varieties in admission and adventure openings are evaluated in the capital market; consequently the stock esteem changes are related to enhancements in money related factors (Goswami and Jung 1997).

A long haul relationship exists between the adjustments in stock costs and the macroeconomic factors, Fama $(1981,1990)$ and Chen et al. (1986) have since quite a while ago settled association with the US monetary raw numbers. Fama (1981) consider demonstrates a solid positive connection between's the normal stock returns and the genuine monetary factors like - genuine
GNP, capital consumptions, modern creation, cash supply, slacked expansion and loan fees. Chen et al. (1986) found that the adjustments in all out creation, expansion, here and now financing costs, the development chance premium and default chance premium are the important monetary variables.

Key examiners trust that stock costs are slanted by impulses in cash supply, expansion rates, premium charges, and extra macroeconomic signs. It draws in a general consistent quality methodology, accentuating the interrelation among fragments as integral to the thought of determination and co-development of macroeconomic period arrangements.

The different monetary written works have been given to the examinations on the connection between security showcase files exhibitions and genuine macroeconomic exercises in the created economies like US and Japan, there are not very many endeavors at disentangling this linkage in creating economies, for example, India. The idea of relationship between stock lists and macroeconomic elements may contrast among created and rising nations' frugalities; this examination endeavors to look at the relationship between some macroeconomic variables (FIIs net venture, Trade Rates, Oil value, Financing costs, Expansion Rates and Gold rates) and securities exchange files exhibitions in Indian security advertise. The examination covers twenty one years from the year $1995-96$ to $2014-15$.

\section{Review of related literature}

Scientists commit that they have recognized $30 \%$ to $35 \%$ of varieties in stock esteem might be certify to economy broad variables (Chandra 2004). Factors occupied with this investigation 
are basically economy nuts and bolts and this investigation thusly offers more realities on basic examination of economy, industry and corporate. The stock value development lay on the execution of basic perspectives. Henceforth, it is contended that corporate profit is the basic to stock esteem assurance and it relies upon number of components, for example, financial advancement, riches and generation, the preparation of brilliant work quality and in addition accessibility of long haul finance (Golob and Diocesan 1997). Different perspectives which transparently or optionally authorize on financial development and flourishing effect the stock conduct. (Oaikhena 2002) Maysami et al. (2005) distinguished short and long haul premium charges, mechanical generation, the different value arranges, the clear trade recurrence and the cash supply utilizing co incorporation for security trades.

From these inquires about, it in this manner implies that there are some key factors that are utilized to characterize the type of the large scale economy that a financial specialist needs to screen and gauge. The coreidea is to get an impression of the expected corporate income and the installment of profits and interests. The key factors included are: the total national output (Gross domestic product), modern development rate, the limit use, level of funds and speculation, the purchaser value level, expansion, parity of installments, loan fees, remote trade saves, trade rates, and the supply of cash. In this work, the scientists have set up some exact verification relating assigned macroeconomic factors to security advertise files.

Remote institutional financial specialists net speculation (FIIs) and stock costs

Remote institutional financial specialists' speculation net streams are considered to build local venture without increment obligation. FIIs may raise the stock costs and animate venture by Indian organizations and prompt change in securities showcase. At the point when FIIs began to pull back cash from the stock exchange, the household speculators wound up dreadful and after that they pull back cash from the market. This show a relationship exist between FIIs net speculation and security advertise lists exhibitions in India.

\section{Swapping scale and stock costs}

Trade is the cost of a unit of a given money in connection to different trades. The execution, reasonability and gainfulness of different businesses and organizations which are real shippers or have been substantial clients of import administrations are significantly affected by the conversion scale of Naira against real trades on the planet (Osamwonyi 2003). Conversion scale is the formation of a nation's outer business and straightly identified with the parity of installments. The equalization of installment shortfall and the force of outside save much of the time impact conversion standard. The theoretical proclamation expresses that there is an idealistic connection between conversion scale and stock costs.

\section{Oil cost and stock costs}

High in Oil cost have negative effect on the economy. The higher the costs of Oil ,different things being equivalent, leads higher costs for the items and might be ideal for the share trading system. Value share costs of the organizations may raise because of higher benefits frame a sound business atmosphere.

Loan cost and stock costs

Intrigue extent fluctuates with time, risk, swelling rate, and yield of capital among others (Chandra 2004). Abberations in premium rate energize substitution among securities exchange, currency advertise outfits, and theoretical exercises. As indicated by Kevin
(2000), the intrigue charges in systematized and orchestrated budgetary portion of the economy are engaged inside foreseen run over money related technique. The confused or tangled budgetary sections of the different rates are not requested and may vary by and large subject to the interest and the supply of assets in the business sectors. The partner needs to think the level and development in intrigue obligations winning in the diverse areas of the economy and evaluates their impact on the general introduction and viability of organizations. In an examination Chandra (2004), states that an ascent in financing cost hoses corporate practicality spot and furthermore tips to an expansion in the decrease rate charged to value speculators; that hostily affects stock rates, and bad habit visa. Thus an ascent in loan cost is foreseen to result dangerously on the working of the association.

Smith (1990) completed an examination on the Unified Conditions of Americas economy; saw and distinguished that stock esteem bounce right away after the Central bank reports a cut in the loan fee or rebate rate. Additionally, Goswami and Jung (1997), in an examination on Korea economy found that stock costs are adversely related to long haul loan fees and decidedly interconnected to shortterm financing cost.

\section{Expansion rate and stock costs}

Chandra (2004) expressed in the work that the impact of expansion rate towards the corporate division has been observed to be bi-directional. Certain organizations may benefit while others will undoubtedly endure. Analysts have figured the relationship among swelling and stock qualities. Fama and Schwert (1977), introduced a proof that stock qualities are contrarily connected together for both the foreseen and the unexpected module of Buyer Value List. It is trusted that normal stock ought to be a fence in logical inconsistency of swelling. Feldstein (1980) discusses that expansion in the rate of swelling decreases share costs due to the association of swelling with the expense framework and methodology. Summers (1981) additionally guarantee that the above impact can clarify an extensive part of the decrease in offer costs. The wellspring of this impact is that, the "verifiable Cost's" system of cheapening and the expense on unimportant capital additions, together in light of the fact that the net profit for stocks to diminish when swelling builds (Amadi and Odubo 2002). Another contention is that financial specialists underestimate corporate stock amid inflationary period since they are unsuccessful to consider the capital gain on corporate obligation, and furthermore they esteem stock to offer a Winning Value Proportion that could be practically identical to ostensible as opposed to genuine loan costs. Indisputably, there is a negative connection between swelling level and stocks esteem.

\section{Gold rate and stock costs}

Gold rate makes an effect in the financial exercises and that is the reason it is trusted that its control has been the main capacity of the focal specialist of any nation. Increment in gold rate drives money markets exhibitions downwards. At the point when securities exchange encounters downwards, at that point the financial specialists will approach the gold market. This shows the connection between gold rate and securities exchange exhibitions. That is the reason it is considered as a main marker. 
Particular reason for the investigation

1. To analyze the patterns in the Macroeconomic elements and security showcase records exhibitions in Indian security advertise.

2. To observationally look at the connection between Macroeconomic elements and security advertise files exhibitions

\section{Hypotheses}

Based on the results of previous studies, this article hypothesizes certain or various relationships amid macroeconomic factors like FIIs net investment, Exchange rate, Oil price. Interest rate, Inflation rate, Gold rate and security market indices performances of Indian capital market.

$\mathrm{H} \mathrm{1:} \mathrm{FIIs} \mathrm{net} \mathrm{investment} \mathrm{will} \mathrm{positively} \mathrm{influence} \mathrm{stock} \mathrm{indices}$ performances (SIP). If FIIs is high then SIP will be high.

$\mathrm{H}$ 2: Exchange rate (ER) will positively influence stock indices performances. If ER is high then SIP will be high.

$\mathrm{H}$ 3: Oil price $(\mathrm{OP})$ will positively influence stock indices performances. If OP is high then SIP will be high.

$\mathrm{H}$ 4: Interest rate (IR) will negatively influence stock indices performances. If IR is high then SIP will be low.

$H$ 5: Inflation rate (IFR) will negatively influence stock indices performances. If IFR is high then SIP will be Low.

$\mathrm{H}$ 6: Gold rate (GR) will negatively influence stock indices performances. If GR is high then SIP will be Low

\section{Methodology}

The information prerequisites for the approach incorporate auxiliary data on key Indian macroeconomic factors, for example, stock records esteems, FIIs net speculation, Trade Rates, Oil value, Loan fees, Swelling Rates and Gold rates. Information on stock lists esteems, FIIs net speculation, Trade Rates, Oil value, Financing costs, Expansion Rates and Gold rates were sourced from different sites of BSE and NSE, SEBI Yearly Reports and Proclamation of Records of the Hold Bank of India. The example time frame covers $1995-96$ to 2014-15, comprising of 21 yearly perceptions for each factor.

The condition indicated depends on the instinctively conceivable suspicion that stock costs and hence securities exchange record can be clarified by incidental components (advertise essentials for this situation). The six speculations could be scientifically composed as pursues:

$\mathrm{SIP}=\mathrm{f}($ FIIs, ER, OP, IR, IFR, GR)

With the variables defined as follows:

Where,

SIP - Stock Market Indices Performances (BSE-Sensex \& NSENifty)

FIIs - Foreign Institutional Investors Net Investment

ER- Exchange Rate

OP- Oil Prices

IR - Interest Rate

IFR- Inflation Rate

GR - Gold Rate

Equation (1) States that Stock indices performances depends upon the FIIs net investment, Exchange rate, Oil price, Interest rate, Inflation rate and Gold rate. For the method of analysis, this study will employ correlation analysis and Multiple regression analysis which will help in investigation of the impacts of the identified variables on the stock market indices performances namely BSESensex, NSE-Nifty.

\section{Empirical analysis, results and discussion}

The first section tries to examine the trends of macroeconomic variables and two major stock indices performances, which are BSE-Sensex and NSE- Nifty. Figure. $1 \& 2$ displays that the trends in the macroeconomic factors and stock indices performances for the past 21 years. It is observed from the Figure $1 \&$ Figure 2, that the drivers of the fall or rise in both BSE- sensex and NSE- Nifty are macroeconomic factors.

BSE sensex and Other Influencing Factors Performances

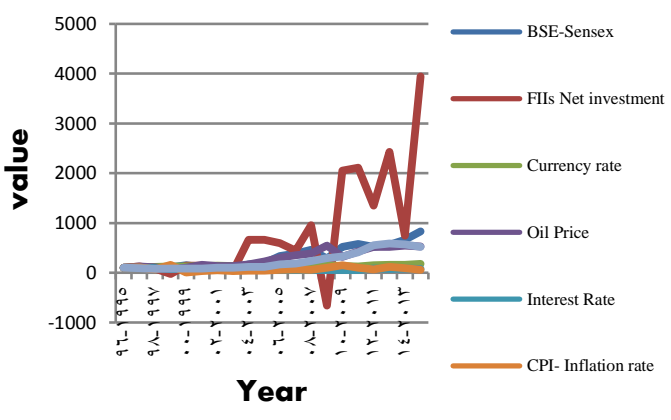

Figure 1: Explains the trends of BSE SENSEX and other influencing factors of stock index performance

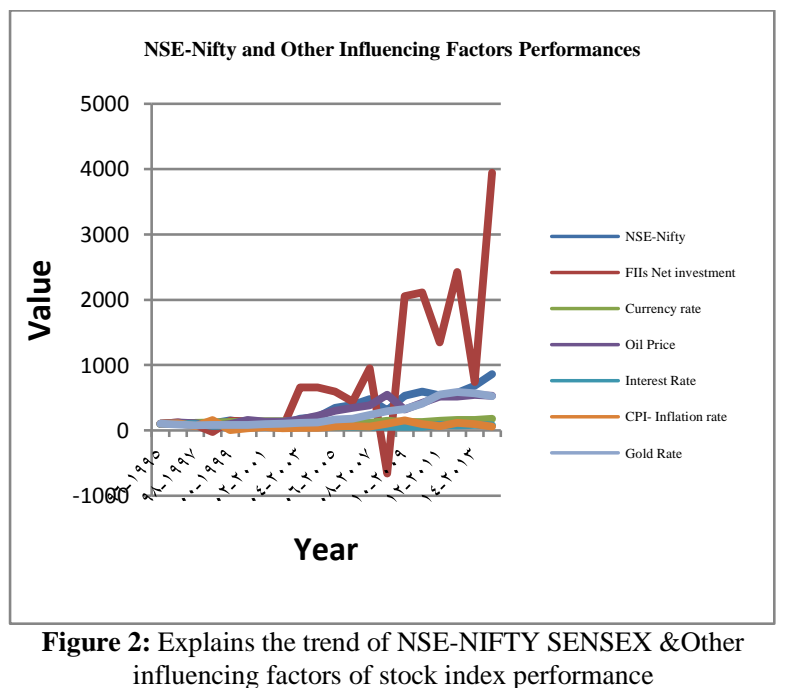

\section{Correlation analysis on macro-economic factors and BSE-sensex stock index performances}

Table 1: Shows Pearson Correlation Coefficient between Macro Economic Factors and BSE- Sensex Performances

\begin{tabular}{|l|l|}
\hline Macro Economic Factors & BSE Sensex Stock Index Performances \\
\hline FIIs Net Investment & $0.829^{* *}$ \\
\hline Currency Rate & $0.668^{* *}$ \\
\hline Oil Price & $0.881^{* *}$ \\
\hline Interest Rate & -0.079 \\
\hline Inflation Rate & 0.239 \\
\hline Gold Rate & $0.908^{* *}$ \\
\hline
\end{tabular}

Note: $* *$ - Indicates Significance at $1 \%$

Source- Processed Secondary Data

* - Indicates Significance at 5\%

The correlation coefficient between FIIs net investment and Stock index performances is 0.829 , which indicate 82.9 percentage positive relationships between FIIs net investment and Stock index performances and is significant at $1 \%$ level. The correlation coefficient between Currency rate and Stock indices performances 
is 0.668 , which indicate $66.8 \%$ positive relationships between Currency rate and Stock index performances and is significant at $1 \%$ level. The correlation coefficient between Oil price and Stock index performances is 0.881 , which indicate 88.1 percentage positive relationships between Oil price and Stock indices performances and is significant at $1 \%$ level. The correlation coefficient between Interest rate and Stock index performances is 0.079 , which indicate $7.9 \%$ negative relationships between Interest rate and Stock index performances and is not significant at $5 \%$ level. The correlation coefficient between Inflation rate and Stock index performances is 0.239 , which indicate $23.9 \%$ positive relationships between Inflation rate and Stock index performances and is not significant at 5\% level and similarly the correlation coefficient between Gold rate and Stock index performances is 0.908 , which indicates $90.8 \%$ positive relationships between Gold rate and Stock index performances and is significant at $1 \%$ level.

\section{Multiple regression analysis of BSE-sensex performances on factors influencing stock market}

In this study, the dependent variable is BSE-sensex performances. Independent variables are FIIs net investment, Currency Rate, Oil price rate, Interest rate, Inflation rate and Gold rate and analysis are discussed as follows:

Coefficient of determination R-square measures the goodness-offit of the projected Sample Regression Plane (SRP), in relation to the proportion of the variation in the dependent variables described by the built-in sample regression equation.

Dependent Variable
Independent Variables

: BSE Sensex Performances $(\mathrm{Y})$
1. FIIs Net Investment $\left(\mathrm{X}_{1}\right)$
2. Currency Rate $\left(\mathrm{X}_{2}\right)$
3. Oil Price $\left(\mathrm{X}_{3}\right)$
4. Interest Rate $\left(\mathrm{X}_{4}\right)$
5. Inflation Rate $\left(\mathrm{X}_{5}\right)$
6. Gold Rate $\left(\mathrm{X}_{6}\right)$
$: 0.969$
$: 0.939$
$: 33.262$
$:=0.001^{* *}$

Table 2: Variables in the Multiple Regression Analysis

\begin{tabular}{|c|c|c|c|c|c|}
\hline \multirow[t]{2}{*}{ Variables } & \multicolumn{2}{|c|}{$\begin{array}{l}\text { Unstandardized } \\
\text { Co-Efficient }\end{array}$} & \multirow{2}{*}{$\begin{array}{l}\text { Standardized } \\
\text { Co-Efficient } \\
\text { Beta }\end{array}$} & \multirow[t]{2}{*}{$\begin{array}{l}\mathbf{t} \\
\text { Value }\end{array}$} & \multirow[t]{2}{*}{$\begin{array}{l}\mathbf{P} \\
\text { Value }\end{array}$} \\
\hline & B & $\begin{array}{l}\text { Std } \\
\text { Error }\end{array}$ & & & \\
\hline Constant & 5857.815 & 7669.653 & & 0.764 & 0.459 \\
\hline $\mathrm{X}_{1}$ & 0.046 & 0.011 & 0.454 & 4.149 & $0.001 * *$ \\
\hline$X_{2}$ & -110.898 & 140.595 & -0.092 & -0.789 & 0.444 \\
\hline$X_{3}$ & 135.360 & 56.830 & 0.515 & 2.382 & $0.033^{*}$ \\
\hline $\mathrm{X}_{4}$ & -145.301 & 388.546 & -0.034 & -0.374 & 0.714 \\
\hline $\mathrm{X}_{5}$ & 18.005 & 159.735 & 0.009 & 0.113 & 0.912 \\
\hline $\mathrm{X}_{6}$ & 1.602 & 2.474 & 0.183 & 0.647 & 0.529 \\
\hline
\end{tabular}

Note: $* *$ - Indicates significance at $1 \%$.

Source- processed secondary data

* - Indicates significance at 5\%.

The anticipated standards are obtained as a linear combination of FIIs net investment $\left(\mathrm{X}_{1}\right)$, Currency rate $\left(\mathrm{X}_{2}\right)$, Oil price $\left(\mathrm{X}_{3}\right)$, Interest rate $\left(\mathrm{X}_{4}\right)$, Inflation rate $\left(\mathrm{X}_{5}\right)$, and Gold rate $\left(\mathrm{X}_{6}\right)$. The multiple correlation coefficient value of 0.969 represents that the association between BSE-Sensex performances and the six independent variables is quite robust and constructive.

The value of $\mathrm{R}$ square is 0.939 and significant at $1 \%$ level, means that about $93.90 \%$ of the variation in stock index performances is explained by the estimated SRP that uses FIIs net investment, Currency rate, Oil price, Interest rate, Inflation rate, and Gold rate, as the independent variables.

The multiple regression equation is
$\mathrm{Y}=5857.815+0.046 \mathrm{X}_{1}-110.898 \mathrm{X}_{2}+135.360 \mathrm{X}_{3}-145.301 \mathrm{X}_{4}+$ $18.005 \mathrm{X}_{5}+1.602 \mathrm{X}_{6}$

Here the coefficient of X1is 0.046 and huge at $1 \%$ level, speaks to the fractional effect of FIIs net venture on BSE-Sensex stock list exhibitions, holding alternate factors as steady. The proposed idealistic sign infers that such impact is hopeful that stock record exhibitions would ascend by 0.046 for each unit ascend in FIIs net speculation. The coefficient of X2is - 110.898 and not huge at 5\% level, signify the incomplete impact of Cash rate on stock file exhibitions, holding alternate factors as steady. The anticipated negative sign infers that such impact is negative that stock file exhibitions would diminish by 110.898 for each unit increment in Cash rate. The coefficient of X3is 135.360 and huge at 5\% level speaks to the incomplete impact of Oil cost on stock lists exhibitions, holding alternate factors as consistent. The anticipated positive sign infers that such impact is certain that stock record exhibitions would increment by 135.360 for each unit increment in Oil cost. The coefficient of X4is - 145.301 and not huge at 5\% level; speak to the halfway impact of loan fee on stock list exhibitions, holding alternate factors as steady. The evaluated negative sign suggests that such impact is negative that stock file exhibitions would diminish by -145.301 for each unit increment in loan fee. The coefficient of X5 is 18.005 and not noteworthy at $5 \%$ level speaks to the incomplete impact of expansion rate on stock record exhibitions, holding alternate factors as steady. The anticipated positive sign infers that such impact is sure that stock file exhibitions would increment by 18.005 for each unit increment in Expansion. The coefficient of X6 is 1.602 and not critical at $5 \%$ level, speaks to the halfway impact of Gold rate on stock record exhibitions, holding alternate factors as steady. The anticipated positive sign suggests that such impact is sure that stock record exhibitions would increment by 1.602 for each unit increment in Gold rate.

In view of institutionalized co-proficient, Oil cost $(0.515)$ is the most essential factor to separate BSE Sensex stock list exhibitions, trailed by FIIs net venture (0.454), and Gold rate (0.183).

\section{Correlation analysis on macro economic factors and NSE-Nifty stock index performances}

The correlation coefficient between FIIs net investment and Stock index performances is 0.832 , which indicate 83.2 percentage positive relationships between FIIs net investment and Stock index performances and is significant at $1 \%$ level. Here, the correlation coefficient between Currency rate and Stock indices performances is 0.680 , which indicate 68 percentage positive relationships between Currency rate and Stock index performances and is significant at $1 \%$ level.

Table 3: Pearson Correlation Coefficient between Macro Economic factors and NSE- Nifty Stock Index Performances

\begin{tabular}{|l|l|}
\hline Macro Economic Factors & NSE Nifty Stock Index Performances \\
\hline FIIs Net Investment & $0.832^{* *}$ \\
\hline Currency Rate & $0.680^{* *}$ \\
\hline Oil Price & $0.885^{* *}$ \\
\hline Interest Rate & -0.088 \\
\hline Inflation Rate & 0.227 \\
\hline Gold Rate & $0.910^{* *}$ \\
\hline
\end{tabular}

Gold Rate

Note: ** - Indicates Significance at $1 \%$.

* - Indicates Significance at 5\%

The correlation coefficient between Oil price and Stock index performances is 0.885 , which indicates 88.5 percentage positive relationships between Oil price and Stock indices performances and is significant at $1 \%$ level. Correlation coefficient between Interest rate and Stock index performances is -0.088 , which indicates 8.8 percentage negative relationships between Interest 
rate and Stock index performances and is not significant at 5\% level. Correlation coefficient between Inflation rate and Stock index performances is 0.227 which indicates 22.7 percentage positive relationships between Inflation rate and Stock index performances and is not significant at 5\% level and similarly the correlation coefficient between Gold rate and Stock index performances is 0.910 , which indicates 91 percentage positive relationships between Gold rate and Stock index performances and is significant at $1 \%$ level.

\section{Multiple regression analysis of NSE-Nifty stock index performances on factors influencing stock market}

In this study, the dependent variable is NSE- Nifty stock index performances. Independent variables are FIIs net investment, Currency Rate, Oil price rate, Interest rate, Inflation rate and Gold rate and analysis are discussed as follows:

Dependent variable: NSE- Nifty Stock Index Performances $(\mathrm{Y})$

Independent variables: 1 . FIIs net Investment $\left(\mathrm{X}_{1}\right)$

2. Currency Rate $\left(\mathrm{X}_{2}\right)$

3. Oil Price $\left(\mathrm{X}_{3}\right)$

4. Interest Rate $\left(\mathrm{X}_{4}\right)$

5. Inflation Rate $\left(\mathrm{X}_{5}\right)$

6. Gold Rate $\left(\mathrm{X}_{6}\right)$

$\begin{array}{ll}\text { The Multiple R Value } & : 0.972 \\ \text { The R Square Value } & : 0.944 \\ \text { The F Value } & : 36.869 \\ \text { The PValue } & : \approx 0.001^{* *}\end{array}$

Table 4: Variables in the Multiple Regression Analysis

\begin{tabular}{|c|c|c|c|c|c|}
\hline \multirow[t]{2}{*}{ Variables } & \multicolumn{2}{|c|}{$\begin{array}{l}\text { Unstandardized } \\
\text { Co-Efficient }\end{array}$} & \multirow{2}{*}{$\begin{array}{l}\text { Standardized } \\
\text { Co-Efficient } \\
\text { Beta }\end{array}$} & \multirow[t]{2}{*}{$\begin{array}{l}\mathbf{t} \\
\text { Value }\end{array}$} & \multirow[t]{2}{*}{$\begin{array}{l}\mathbf{P} \\
\text { Value }\end{array}$} \\
\hline & B & $\begin{array}{l}\text { Std } \\
\text { Error }\end{array}$ & & & \\
\hline Constant & 1625.872 & 2197.253 & & 0.740 & 0.472 \\
\hline $\mathrm{X}_{1}$ & 0.014 & 0.003 & 0.453 & 4.347 & $0.001 * *$ \\
\hline$X_{2}$ & -27.938 & 40.279 & -0.077 & -0.694 & 0.500 \\
\hline$X_{3}$ & 40.722 & 16.281 & 0.515 & 2.501 & $0.027 *$ \\
\hline $\mathrm{X}_{4}$ & -48.682 & 111.313 & -0.038 & -0.437 & 0.669 \\
\hline $\mathrm{X}_{5}$ & 0.146 & 45.762 & 0.000 & 0.003 & 0.997 \\
\hline $\mathrm{X}_{6}$ & 0.467 & 0.709 & 0.177 & 0.659 & 0.522 \\
\hline
\end{tabular}

Note: $* *$ - Indicates Significance at $1 \%$.

* - Indicates Significance at 5\%.

The projected values are obtained as a linear combination of FIIs net investment $\left(\mathrm{X}_{1}\right)$, Currency rate $\left(\mathrm{X}_{2}\right)$, Oil price $\left(\mathrm{X}_{3}\right)$, Interest rate $\left(\mathrm{X}_{4}\right)$, Inflation rate $\left(\mathrm{X}_{5}\right)$, and Gold rate $\left(\mathrm{X}_{6}\right)$. The multiple correlation coefficient value of 0.972 denotes that there exist the positive relationship between NSE-Nifty stock index performances and the six independent variables.

$\mathrm{R}$ square is 0.944 and significant at $1 \%$ level, means that about $94.40 \%$ of the variation in stock index performances is explained by the estimated SRP that uses FIIs net investment, Currency rate, Oil price, Interest rate, Inflation rate, and Gold rate, as the independent variables.

The multiple regression equation is

$\mathrm{Y}=1625.872+0.014 \mathrm{X}_{1}-27.938 \mathrm{X}_{2}+40.722 \mathrm{X}_{3}-48.682 \mathrm{X}_{4}+0.146 \mathrm{X}_{5}+0.467 \mathrm{X}_{6}$

Here the coefficient of X1is 0.014 and huge at $1 \%$ level, speaks to the incomplete effect of FIIs net speculation on NSE Clever stock file exhibitions, holding alternate factors as consistent. The anticipated positive sign gathers that such impact is idealistic that stock file exhibitions would flood by 0.014 for each unit increment in FIIs net speculation. The coefficient of X2 is 27.938 and not noteworthy at $5 \%$ level, speaks to the incomplete impact of Cash rate on stock file exhibitions, holding alternate factors as steady. The assessed negative sign infers that such impact is negative that stock record exhibitions would diminish by 27.938 for each unit increment in Money rate. The coefficient of $\mathrm{X} 3$ is 40.722 andsignificant at $5 \%$ level, speaks to the incomplete impact of Oil cost on stock records exhibitions, holding alternate factors as consistent. The anticipated positive sign infers that such impact is sure that stock file exhibitions would ascend by 40.722 for each unit increment in Oil cost. The coefficient of X4 is 48.682 and not critical at $5 \%$ level speak to the incomplete impact of loan cost on stock list exhibitions, holding alternate factors as steady. The assessed negative sign infers that such impact is negative that stock record exhibitions would diminish by -48.682 for each unit increment in loan fee. Coefficient of X5 is 0.146 and not huge at 5\% level implies the incomplete impact of swelling rate on stock file exhibitions, holding alternate factors as consistent. The anticipated positive sign suggests that such impact is certain that stock file exhibitions would increment by 0.146 for each unit increment in Expansion. Correspondingly, the coefficient of X6 is 0.467 and not huge at 5\% level, implies the incomplete impact of Gold rate on stock record exhibitions, holding alternate factors as consistent. The anticipated positive sign suggests that such impact is sure that stock record exhibitions would increment by 0.467 for each unit increment in Gold rate.

In light of institutionalized co-effective, Oil cost (0.515) is the most vital factor to extricate NSE Clever stock list exhibitions, trailed by FIIs net venture (0.453), and Gold rate (0.177).

\section{Findings of the study}

The results show that there exist some connection between macroeconomic factors and driving stock records exhibitions. From the tables 1.2 and 2.2, the result demonstrates that FIIs net speculation, Conversion standard, Oil costs, Loan cost, Expansion rate, and Gold costs do influence Offer market records. FIIs net speculation is emphatically critical at $1 \%$ level, while Oil cost is decidedly noteworthy at 5\% level. It is additionally discovered that Conversion standard and Loan cost impact antagonistically on offer records exhibitions, however not factually huge. In any case, swelling rate and gold rate are decidedly influenced to stock records exhibitions, however not factually critical. The most vital factor that impacts securities exchange files is Oil cost pursued by FIIs and Gold rate.

The results of the examination affirm the speculation 1 (H1). FIIs net speculation is emphatically related tosecurity files exhibitions. This is like discoveries of Azad et.al (2013), they found that the FIIs net venture are associated with the share trading system return as well as reasonably clarifies the conduct of the offer market. Everywhere throughout the investigation infers that if FIIs are sure about Indian markets, there is a general observation that market is on the ascent.

Trade rates are adversely identified with BSE-Sensex and NSEClever. Thus the theory 2 (H2) isn't affirmed. The Indian economy is an open economy where outside segment assume a noteworthy job in the capital serious oil and gas part. Conversion scale impacts contrarily as the long haul development is disabled and in addition the parity of installments by acknowledging Swapping scale. This clarifies why it isn't huge.

Oil cost is decidedly identified with stock records exhibitions. Here the speculation 3 (H3) is affirmed. The clarification for this relationship is that expansion in oil value impacts for the most part all costs in the economy including stock costs.

Loan fee unfavorably influences BSE-Sensex and NSE-Clever. The speculation $4(\mathrm{H} 4)$ is likewise affirmed. They have been observed to be reliably not measurably critical at $5 \%$ level. The negative sign is reliable with hypothesis as low rates mean greater interest in stocks both because of portfolio impacts and moderate wellsprings of financing. 
Swelling rate is decidedly identified with Stock lists exhibitions. It isn't huge at $5 \%$ level. In this way the speculation 5 (H5) isn't affirmed. The clarification for this relationship is that rising expansion pushes the costs of offers and in this manner advertise record upward, particularly when comes back to shares are normal that a high and rising swelling rate serve to dissolve the genuine estimation of monetary resources, stock costs comprehensive. It is demonstrative that riches holders would tend to move their riches holding for genuine advantages for the relative disregard of monetary resources.

Gold rate is emphatically identified with stock lists exhibitions. Thusly theory 6 (H6) is additionally not affirmed.

\section{Conclusion}

The prime point of the investigation was to plan and look at, factors affecting connection between the chose macroeconomic components impacting securities exchange conduct and Stock lists exhibitions in Indian capital market. We expected a connection between Stock lists exhibitions as intermediary at stock costs in Indian capital market and chose macroeconomic factors. This relationship show was tried by utilizing Connection examination and different relapse investigation with the previous multi year's information and we found that Securities exchange lists are affected by some large scale financial variables.

In accordance with this, the evaluations additionally recommend the requirement for strategy creators to plan arrangements that will reduce fast development in cash supply. There is additionally the need to define strategies that are equipped for improving the national wage of the nation. Fare arrangements ought to be empowered, as they ascend to issue of parity of installments, their shortage or surplus and furthermore in charge of the gratefulness or generally of a country's outside trade.

\section{References}

[1] Abeyratna G, Pisedtasalasai A \& Power D, "Macroeconomic Variables Influence on the Stock Market. Evidence form an Emerging Market in South Asia", Journal of Emerging Market Finance, Vol.3, No.3,(2003).

[2] Amadi SN \& Odubo TD, "Macroeconomic Variables and Stock Prices: Causality Analysis", The Nigeria Journal of Economic and Management Studies, Vol.4, (2002), pp. 29-41.

[3] Bilson C, Brailsford TJ \& Hooper V, "Selected Macroeconomic Variables as Explanatory Factors of Emerging Stock Market Returns", Working Paper Series From <http://ssrn.com/abstract201908, (1992)

[4] Bombay Stock Exchange 1995-96-2014-15 Fact book www.nseindia.com

[5] National Stock Exchange 1995-96-2014-15 fact book www.bseindia.com, www.moneycontrol.com

[6] Chandra P, Investment Analysis and Port Folio Management, New Delhi McGraw -Hill, (2004)

[7] Chen N, "Financial Investment Opportunities and the Macro Economy", Journal of Finance, Vol.46, No.2, (1991), pp.529-554.

[8] Chen N, Roll R \& Ross S, "Economic Forces and the Stock Market", Journal of Business, Vol.59, (1986), pp.383-403

[9] Fama E, "Stock Returns Real Activity Inflation and Money American", Economic Review, Vol.71, (1981), pp. 545-565.

[10] Edmund Christopher S, "Relaunching the Retailing in Small Towns: New Growth Frontiers Open Up in Rural India",
International Journal of Marketing, Financial Services \& Management Research Vol.3,No.7,(2014),pp.57-66.

[11] Edmund Christopher S,"Reengineering the Process of Performance Evaluation towards the Employee's Development - Need of the Time in IT Industry", Journal of Chemical and Pharmaceutical Sciences, (2016), pp.1823-1826.

[12] Edmund Christopher S, "Performance of Air India with Special Reference to Passenger Fluctuations-A Focus", Indian Stream Research Journal, Vol.4, No.10, (2014), pp.01-06.

[13] Dhanya JS \& Kinslin D, “A Study on Impact of Work Life Balance on Retention of Women Teachers in Management Colleges in Kerala", International Journal of Applied Business and Economic Research, Vol.15, No.4, (2017).

[14] Dhanya JS \& Kinslin D, "A Study on Work Life Balance of Women Employeees at ULCCS Ltd., Kozhikode", International Journal of Applied Business and Economic Research, Vol.15, No.4, (2017)

[15] Dhanya JS \& Kinslin D, "Clair Model for Better Work Life Balance and Empowerment of Women Faculty in Professional Colleges of Kerala", International Journal of Applied Business and Economic Research, Vol.15, No.4, (2017).

[16] Kochukalam C \& Kinslin D, "A Study on the Factors for Intermediary Dependence Among Decorative Paint Customers Exploring the impact significance", International Journal of Applied Business and Economic Research, Vol.15, No.6, (2017).

[17] Kochukalam C \& Kinslin D, "A Study Among Decorative Paint Customers on Factors Influencing Preference of Decorative Pain Brands", International Journal of Applied Business and Economic Research, Vol.15, No.6, (2017).

[18] Edmund Christopher S, "A Whiff of IT Industry Work Stress and Accelerating the Productivity: with Special Reference to Indian IT Industry", Zenith International Journal of Business Economics and Management Research, (2014).

[19] Edmund Christopher S, "Drain the Women Entrepreneurial Effort to Manage Global Crisis is The Need of an Hour-A Focus Based on Indian Context", GE-International Journal of Management Research (GE-IJMR), (2016), pp.87-97.

[20] Edmund Christopher S, "An analytical Study on Service Quality of Air India with Special Reference to Southern Region", International Journal of Applied Engineering Research, Research India Publications, Vol.10, No.45, (2015), pp.32021-32024.

[21] Edmund Christopher S, "Employee Training and Developmen Practices in Air India-A Descriptive Glance with Reference to Chennai", International Journal of Applied Engineering Research, Research India Publications, Vol.10, No.45, (2015), pp.3200532008.

[22] Kochukalam C \& Kinslin D, "Problems and Challenges of Decorative Paint Customers in Paint Preference: A Study Among Decorative Paint Customers of Kerala", International Journal of Applied Business and Economic Research, Vol.15, No.6, (2017).

[23] Kochukalam C \& Kinslin D, "A study Explaining Branding Brand Experience Among Decorative Paint customers", Internationa Journal of Applied Business and Economic Research, Vol.15, No.6, (2017)

[24] Shaji Y, Kinslin D \& Janardhanan KA, "Employee Retention Practices for Leaders-A Study in Information Technology Organization", International Journal of Applied Engineering Research, Vol.10, (2015).

[25] Goswamy G \& Jung SC, "Stock Market and Economic Forces Evidence From Korea", IMF Working Paper, (1997).

[26] Osamwonyi IO \& Evbayiro-Osagie EI, "The relationship between macroeconomic variables and stock market index in Nigeria", Journal of Economics, (2012), pp.55-63.

[27] Maysami RC, Loo SW \& Koh TK, "Co-Movement among Sectoral Stock Market Indices and Integration among Dually Listed Companies", Journal of Pengurusan, Vol.23, (2004), pp.33-52.

[28] Maysami RC, Howe LC \& Rahmat MA, "Relationship between macroeconomic variables and stock market indices: Cointegration evidence from stock exchange of Singapore's All-S sector indices", Journal Pengurusan (UKM Journal of Management), (2005). 


\begin{tabular}{|l|l|l|l|l|l|l|l|}
\hline Year & $\begin{array}{l}\text { BSE- } \\
\text { Sensex }\end{array}$ & $\begin{array}{l}\text { FIIs Net } \\
\text { Investment }\end{array}$ & Currency Rate & Oil Price & Interest Rate & $\begin{array}{l}\text { CPI- Inflation } \\
\text { Rate }\end{array}$ & Gold Rate \\
\hline $1995-96$ & 100 & 100 & 100 & 100 & 100 & 100 & 100 \\
\hline $1996-97$ & 99.82852 & 123.5229 & 104.556 & 122.1491 & 100 & 107.4304 & 90.69746 \\
\hline $1997-98$ & 115.6264 & 85.82499 & 114.9782 & 111.2835 & 95.45454 & 64.9123 & 78.43534 \\
\hline $1998-99$ & 111.088 & -22.8175 & 123.5371 & 71.1044 & 72.72727 & 158.1012 & 82.02941 \\
\hline $1999-00$ & 148.553 & 145.8074 & 126.9432 & 98.86557 & 72.72727 & 4.850362 & 84.98923 \\
\hline $2000-01$ & 107.0609 & 143.0849 & 135.7787 & 163.5222 & 63.63636 & 35.91332 & 81.18374 \\
\hline $2001-02$ & 103.0501 & 126.231 & 142.067 & 137.3133 & 59.09091 & 53.25079 & 97.03994 \\
\hline $2002-03$ & 90.55613 & 38.73505 & 138.2969 & 136.179 & 56.81818 & 33.02374 & 101.9025 \\
\hline $2003-04$ & 166.0576 & 659.2304 & 126.4774 & 165.3133 & 54.54545 & 38.3901 & 117.5473 \\
\hline $2004-05$ & 192.8562 & 660.9014 & 127.3799 & 224.8356 & 54.54545 & 39.0093 & 120.2957 \\
\hline $2005-06$ & 335.0487 & 597.3321 & 129.8544 & 298.746 & 54.54545 & 57.48195 & 165.3273 \\
\hline $2006-07$ & 388.2806 & 444.2646 & 126.9141 & 348.0593 & 54.54545 & 67.38908 & 182.0292 \\
\hline $2007-08$ & 464.6868 & 953.3085 & 116.4047 & 383.2832 & 54.54545 & 56.86276 & 234.8832 \\
\hline $2008-09$ & 288.3716 & -659.907 & 148.3115 & 546.1487 & 54.54545 & 100.1032 & 292.8112 \\
\hline $2009-10$ & 520.6274 & 2054.988 & 131.3974 & 319.2832 & 54.54545 & 154.4892 & 324.5236 \\
\hline $2010-11$ & 577.5814 & 2109.439 & 129.9709 & 425.1339 & 54.54545 & 97.72964 & 411.2041 \\
\hline $2011-12$ & 516.957 & 1350.123 & 148.9374 & 519.6412 & 86.36364 & 66.97628 & 551.7958 \\
\hline $2012-13$ & 559.4789 & 2425.327 & 158.3386 & 516.1786 & 77.27273 & 115.2735 & 587.7365 \\
\hline $2013-14$ & 664.9394 & 744.0038 & 158.8617 & 544.2979 & 81.81818 & 94.22087 & 567.652 \\
\hline $2014-15$ & 830.4213 & 3944.608 & 178.2096 & 531.8203 & 77.27273 & 60.47473 & 522.1975 \\
\hline
\end{tabular}

\begin{tabular}{|c|c|c|c|c|c|c|c|}
\hline \multicolumn{8}{|c|}{$\begin{array}{r}\text { Annexure 2 } \\
\end{array}$} \\
\hline Year & NSE-Nifty & $\begin{array}{l}\text { FIIs Net } \\
\text { Investment }\end{array}$ & $\begin{array}{l}\text { Currency } \\
\text { Rate }\end{array}$ & Oil Price & Interest Rate & $\begin{array}{l}\text { CPI- Inflation } \\
\text { Rate }\end{array}$ & Gold Rate \\
\hline $1995-96$ & 100.0001 & 100 & 100 & 100 & 100 & 100 & 100 \\
\hline 1996-97 & 98.295 & 123.5229 & 104.556 & 122.1491 & 100 & 107.4304 & 90.69746 \\
\hline $1997-98$ & 113.3564 & 85.82499 & 114.9782 & 111.2835 & 95.45454 & 64.9123 & 78.43534 \\
\hline $1998-99$ & 109.4135 & -22.8175 & 123.5371 & 71.1044 & 72.72727 & 158.1012 & 82.02941 \\
\hline $1999-00$ & 155.1254 & 145.8074 & 126.9432 & 98.86557 & 72.72727 & 4.850362 & 84.98923 \\
\hline $2000-01$ & 116.5331 & 143.0849 & 135.7787 & 163.5222 & 63.63636 & 35.91332 & 81.18374 \\
\hline $2001-02$ & 114.6403 & 126.231 & 142.067 & 137.3133 & 59.09091 & 53.25079 & 97.03994 \\
\hline $2002-03$ & 99.27947 & 38.73505 & 138.2969 & 136.179 & 56.81818 & 33.02374 & 101.9025 \\
\hline 2003-04 & 179.8337 & 659.2304 & 126.4774 & 165.3133 & 54.54545 & 38.3901 & 117.5473 \\
\hline $2004-05$ & 206.6022 & 660.9014 & 127.3799 & 224.8356 & 54.54545 & 39.0093 & 120.2957 \\
\hline $2005-06$ & 345.3316 & 597.3321 & 129.8544 & 298.746 & 54.54545 & 57.48195 & 165.3273 \\
\hline 2006-07 & 387.8568 & 444.2646 & 126.9141 & 348.0593 & 54.54545 & 67.38908 & 182.0292 \\
\hline $2007-08$ & 480.5139 & 953.3085 & 116.4047 & 383.2832 & 54.54545 & 56.86276 & 234.8832 \\
\hline $2008-09$ & 306.6023 & -659.907 & 148.3115 & 546.1487 & 54.54545 & 100.1032 & 292.8112 \\
\hline $2009-10$ & 532.7417 & 2054.988 & 131.3974 & 319.2832 & 54.54545 & 154.4892 & 324.5236 \\
\hline $2010-11$ & 592.079 & 2109.439 & 129.9709 & 425.1339 & 54.54545 & 97.72964 & 411.2041 \\
\hline $2011-12$ & 537.4763 & 1350.123 & 148.9374 & 519.6412 & 86.36364 & 66.97628 & 551.7958 \\
\hline $2012-13$ & 576.7334 & 2425.327 & 158.3386 & 516.1786 & 77.27273 & 115.2735 & 587.7365 \\
\hline $2013-14$ & 680.4227 & 744.0038 & 158.8617 & 544.2979 & 81.81818 & 94.22087 & 567.652 \\
\hline 2014-15 & 861.7686 & 3944.608 & 178.2096 & 531.8203 & 77.27273 & 60.47473 & 522.1975 \\
\hline
\end{tabular}

